\title{
NOTES AND COMMUNICATIONS
}

\author{
HOME AND MORTGAGE OWNERSHIP OF THE DUTCH ELDERLY: EXPLAINING \\ COHORT, TIME AND AGE EFFECTS ${ }^{* * * *}$
}

\begin{abstract}
Summary
The relationship between home ownership of Dutch elderly households and age is strongly negative. Other studies suggest that this age gradient should be attributed to a cohort effect. In this paper, we investigate where those cohort effects come from. We also observe that mortgage ownership among elderly home owners increased considerably during the nineties. Using panel data, we estimate models explaining home and mortgage ownership by age, cohort, and time effects, as well as other factors. Cohort and time effects are modelled explicitly using macro economic and housing market related variables. We find that the level of GDP per capita when the household head was young is the main factor explaining generation effects in home ownership among the elderly. After accounting for cohort effects it also appears that home ownership decreases slightly with age. Mortgage ownership among elderly home owners rose considerably during the nineties due to house price increases and due to financial innovation in the mortgage market. Cohort effects are also important. A supplementary analysis suggests that those cohort effects are due to the fact that the accidental bequest motive is becoming less important.
\end{abstract}

Key words: cohort effects, home ownership, mortgages

JEL Code(s) D12, D14, D91

\section{INTRODUCTION}

This paper examines, among other things, the degree to which Dutch elderly households reduce their home ownership. There is considerable interest in the wealth holdings of the elderly, for several reasons. First of all, due to population ageing, the elderly's wealth position is of particular interest from a policy perspective. If the elderly have not saved enough to sustain themselves in old age, this may have dramatic consequences for the society as a whole. A second reason to be interested in the home ownership of the elderly is that it provides a prima facie test of the life cycle hypothesis. This paper can be seen as a follow-up study to Alessie et al. (1995) who have used panel data covering the period 1987-1991. Roughly speaking, they have found that the median Dutch elderly household did not own a home at the beginning of the 1990s. Consequently, the asset holdings of the median household were so small that they

**** We thank Maarten van Rooij, Konstantinos Tatsiramos, Casper van Ewijk, Wouter Vermeulen, Frederic Vermeulen, Frank de Jong and Marcel Lever for their useful comments 
could finance consumption for a few months: they only served as a buffer for adverse shocks. Consumption of the median retired household was financed through social security and occupational pension income.

The picture sketched by Alessie et al. (1995) has changed dramatically during the nineties. Home ownership rates among elderly households in the Netherlands rose by more than $10 \%$ points during that period. Nevertheless, the home ownership rate is still considerably lower than in other European countries and the US. Moreover, the relationship between home ownership and age is rather peculiar in the Netherlands: in 1990 about 54\% of all households at age 55 and $30 \%$ around age 75 owns a house. Such a strong age gradient is not observed in other developed countries. In the United Kingdom, the US and Italy the average percentage of households with an own house is, respectively, $75 \%, 78 \%$ and $70 \%$ between age 50 and 59. This is still $57 \%, 75 \%$ and $66 \%$ between age 70 and 79 (Chiuri and Jappelli (2000)). Analysis on panel data by Alessie and Kapteyn (2002) shows that the strong negative cross-sectional relationship between home ownership and age among elderly Dutch households should be presumably attributed to a cohort effect. This finding suggests that on average the generations born after World War II (will) enter the retirement phase with much more wealth than the generations born before $1930^{1}$. If the younger generations retire, private wealth will not only serve as a buffer for adverse shocks but can also be used for consumption purposes or for (intentional) bequests. For policy analysis it is interesting to know where those strong cohort effects in home ownership come from and whether or not generations born after, say, 1960 will be predominantly home owners when they enter retirement. In this paper, we try to answer this type of questions. Using a panel data set covering the period 1990-2002, we explain those cohort effects on basis of macro economic and housing market related variables. One important cohort effect might stem from the fact that due to productivity growth younger generations have a higher lifetime income (permanent income) than the older ones. Like Kapteyn et al. (2005), we try to capture this productivity growth effect by means of real GDP per capita level when the household head was young (between age 23 and 27).

We also consider housing market conditions around age 25 as measured by the supply of the new houses in the rental and owner occupied sector, respectively. Due to the highly regulated housing market policies in the Netherlands, housing market conditions at young ages might have had a long-term effect on the home ownership status at a later stage of the life cycle ${ }^{2}$. Just after World War II there was a large housing shortage. Therefore, the government

1 This older generation has been investigated by Alessie et al. (1995).

2 In order to investigate this long-term effect in more detail, we also estimate the home ownership equation on a subsample consisting of households with a head who is at least 50 years old. 
planned to build many subsidised dwellings in a short period. Until 1975, the annual number of newly built rented dwellings was larger than the production of owner-occupied houses. Consequently, many households born in the 1920s, 1930s (and 1940s) ended up in a rental dwelling when they were young. Rents of subsidised dwellings were and are still low due to the highly regulated policies by the central and local governments. Given these low rents, it might have been attractive for the older generations not to move to an owner occupied house at an older age, even in the case that household income has increased considerably. According to criteria set by the government approximately a quarter of all tenants should, regarding their income, not occupy a council house (this number refers to 1989, see Ministry of Housing (1999)). From the 1990s onwards, government policy is geared towards stimulating home ownership. Consequently, in the nineties the number of newly built owner-occupied dwellings is considerably larger than the number of new houses in the rental sector.

We are also interested in the question whether retired households use their housing wealth to finance consumption as predicted by the life cycle model (see Deaton (1992), Hurd (1989) for an overview of the life cycle model). One of the ways to cash housing wealth for consumption purposes is to sell the house and to rent afterwards. Therefore it is interesting to investigate the relationship between home ownership and age after having corrected for cohort effects.

Instead of becoming a renter, elderly home owners could finance consumption by taking up a mortgage. In this paper, we show that during the nineties mortgage ownership among elderly home owners increased even more dramatically than home ownership. Moreover, it appears that mortgage redemption between the age of 60 and 70 is less popular than one might expect. The increase in mortgage ownership among elderly home owners are not only due to cohort effects. Macroeconomic and institutional changes which took place during our sample period (1990-2002) could also have played a role. The 1990s (and especially the second half of the 1990s) witnessed a higheconomic growth, low-real interest rates and large increases in house prices. Moreover, new mortgage types were introduced which exploit as much as possible the tax deductibility of mortgage interest payments ${ }^{3}$.

In our analysis of the home ownership and mortgage decision we should take into account that in 1993 banks relaxed the mortgage qualification constraint for two earner couples. Before that year, banks typically considered only the income of the husband in determining the maximum allowable mort-

3 Up to 1999, all mortgage interest payments were tax deductible. In 2000, the tax authorities curtailed the deductibility a bit. Interest payments are not anymore tax deductibility if the mortgage is used to finance stock market operations or durable goods (such as a car or sailing boat). In 2002, the tax authorities curtailed the tax deductibility of mortgage interest payments somewhat further. 
gage loan. From 1993 onwards, banks also take the earnings of the wife into account (Van Assenbergh (1998)). Obviously, such (institutional) changes might have affected households' decisions concerning home and mortgage ownership. Furthermore, we should account for the fact that large increases in the housing wealth appear to stimulate the take up of second mortgages among elderly (Rouwendal and Alessie (2002)), (Haffner (2005)). Groeneveld and de Haas (1999) mention 'a reduction in the Calvinism' in the investment and financing behaviour as a possible explanation for this phenomenon.

The study is organized as follows. In the next section, we present the data and show that mortgage ownership among elderly home owners has increased by about $10 \%$ between 1990 and 2002. In section 3, we present the reduced form model that accounts for cohort, time and age effects as well as socioeconomic related variables. Section 4 shows the empirical results. In section 5, we further explore the cohort effects related to the changes in mortgage ownership. We end with the conclusions in section 6.

\section{DATA}

For the analysis of home and mortgage ownership we mainly use data which stems from the Dutch Social Economic Panel (SEP). The SEP is a longitudinal survey which is administered by Statistics Netherlands (CBS) between 1984 and 2002. It consists of approximately 4,600 households per year. The aim of the SEP is to provide a description of the most important elements of individual and household welfare, and to monitor changes in these elements over time. The SEP questionnaire includes detailed questions on income, wealth (as of 1987), labour force participation, demographics etcetera. The sample is representative of the Dutch population excluding those living in special institutions such as nursing homes. We only use data from 1990 to 2002, because in 1990 CBS revised the income questions dramatically. For further information on the data, see e.g. Alessie et al. (1997).

The SEP dataset does not contain enough information to explain the observed cohort and time effects in mortgage ownership among the elderly (see below). Therefore we also perform some additional analysis on data sponsored by the Nederlandsche Bank (DNB). The DNB Household Survey (DHS) was formerly known as the CentER panel or VSB panel. Nyhus (1996) describes this data set and its general quality. From 1993 onwards, the DHS-data are collected by CentERdata on an annual basis. The DHS-data covers about 2,000 households each year ${ }^{4}$. The survey contains interesting questions on the housing situation of a household and its savings and bequest motives. Unfortunately, compared with the SEP the attrition rate in this panel

4 The DHS-survey is an internet survey. In the DHS, higher income deciles are somewhat over-represented. We correct for this by using sample weights. 
is rather high: on average, a household participates in the DHS for a period of 3.7 years. The corresponding number in the SEP is 6.1 years.

We select a subsample of households of which the head is between 25 and 80 years old. We delete the $80+$ observations in order to prevent possible problems due to differential mortality. Since rich households tend to live longer the relationship between age and home (mortgage) ownership may be biased, especially in later life (Hurd (1990)).

\subsection{Descriptive Analysis}

In Figure 1, we present age and cohort patterns of the home ownership rate based upon 13 waves of the SEP (1990-2002). We use 5-year-of-birth cohorts, with birth years 1917-1921 for the oldest cohort until birth years 1962-1966 for the youngest cohort. Cohort labels indicate the middle year-of-birth of the household head. The 13 points for each cohort represent the home ownership rate at 13 age levels, and form a 'cohort curve'. For each cohort, these 13 points are interconnected. Jumps between cohort curves show that, apart from age effects, there are cohort or time effects 5 . The fact that cohort curves are not horizontal shows that there are time and/or age effects; the fact that not all cohort curves are the same shows that there is more than just time effects. As usual, however, cohort, time and age effects cannot be disentangled without further assumptions. In the discussion below and in the econometric analysis (see section 4) we ignore time effects. This assumption implies that home ownership is not affected by business cycle shocks during the sample period $^{6}$. Basically, we assume that business cycle shocks are unanticipated and therefore independent of all explanatory variables. In other words, we assume that the business cycle shocks are part of the error term in the model.

A first glance at Figure 1 suggests that the age-home ownership profile has a hump shaped form: home ownership increases up to the age of 55 and gradually declines with age afterwards. The vertical differences between the curves indicate differences in home ownership between cohorts at the same age. Those differences are sometimes large, indicating strong cohort effects in

5 Time effects are changes that occur during the sample period and that affect all households in the sample in the same way each period.

6 In a sensitivity analysis, we have checked the validity of this assumption by adding time specific variables such as growth in real GDP per capita, real interest rate and house prices (in real terms). This does not affect dramatically our results on home ownership reported in Section 4.1. For instance, the age coefficients and the effect of the cohort variables on home ownership do not change much by adding the time specific variables (see Van der Schors et al. (2007) for more details on the sensitivity analysis). Moreover, it should be mentioned that the econometric model takes the whole of transitory income into account. Transitory income could partly capture business cycle effects. However, we do not include a full set of time dummies. Also in other empirical studies on home ownership, for example (Chiuri and Jappelli (2006)), time effects are not taken into account. 


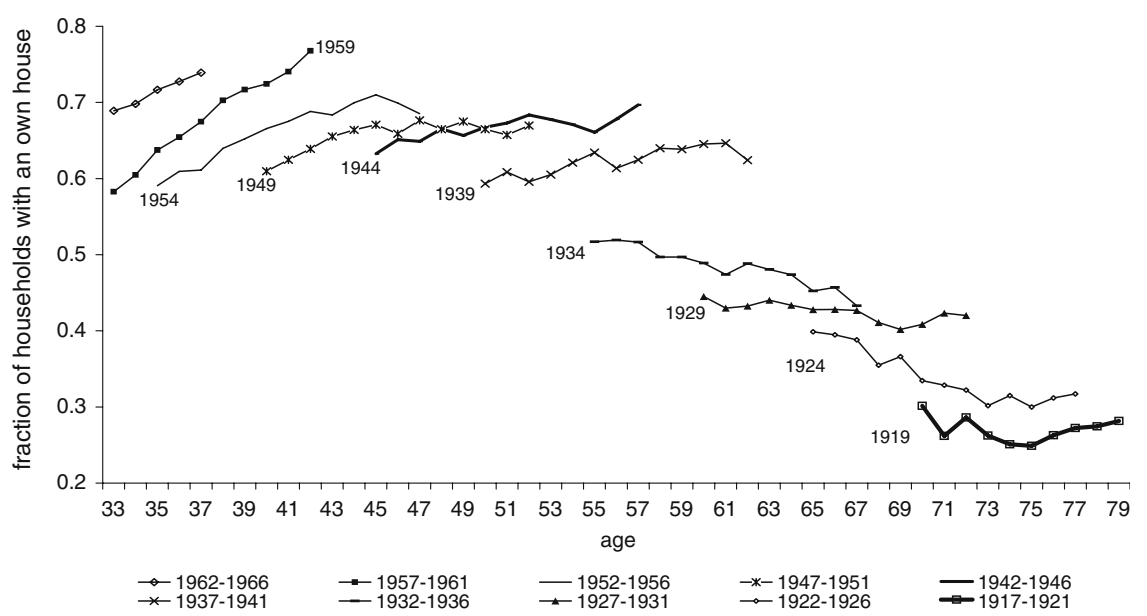

Figure 1 - Home ownership by age and cohort.

Source: SEP, own computations

home ownership. For instance, from all households of which the head was born between 1932 and 1936, approximately 52\% owned a house at the age of 56. This rate has increased to 63\% for those born between 1937 and 1941 at the same age. So, there is a difference in home ownership of more than $10 \%$-points between two adjacent cohorts.

Not surprisingly, the increase in home ownership is matched by a rise in mortgage ownership. It is more interesting to analyse the probability of having at least one mortgage outstanding on its current dwelling conditional upon home ownership.

Figure 2 plots the cross-section relationship between mortgage ownership rate among home owners and age in 1990 and in 2002. In this figure people younger than forty are not considered: young home owners typically have an mortgage outstanding. Figure 2 clearly shows that between 1990 and 2002 the fraction of elderly home owners with a mortgage debt increased considerably: in 2002, $72 \%$ of all home owners aged 65 still had a mortgage. In 1990 this percentage was considerably lower, namely $45 \%$. Such cohort-time effects are hardly observed before the age of 50 .

Similar to Figure 1, Figure 3 shows differences in mortgage ownership over age and between different cohorts of home owners. Contrary to the econometric analysis of home ownership, we argue that time effects should be taken into account when explaining mortgage ownership. The introduction of new mortgage types and the increased liberalisation of the mortgage market during the sample period could have affected household's mortgage behaviour. However, the inclusion of time effects leads to an identification problem, since 


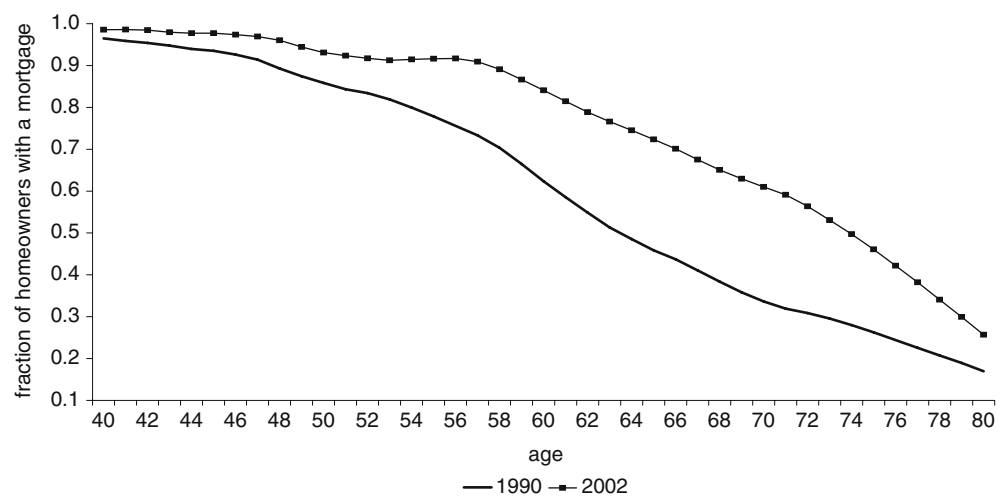

Figure 2 - Mortgage ownership among home owners by age in 1990 and 2002. Explanatory note: non-parametric regression technics (lowess smoothing) has been used to estimate the relationship between age and mortgage ownership. Source: SEP, own computations

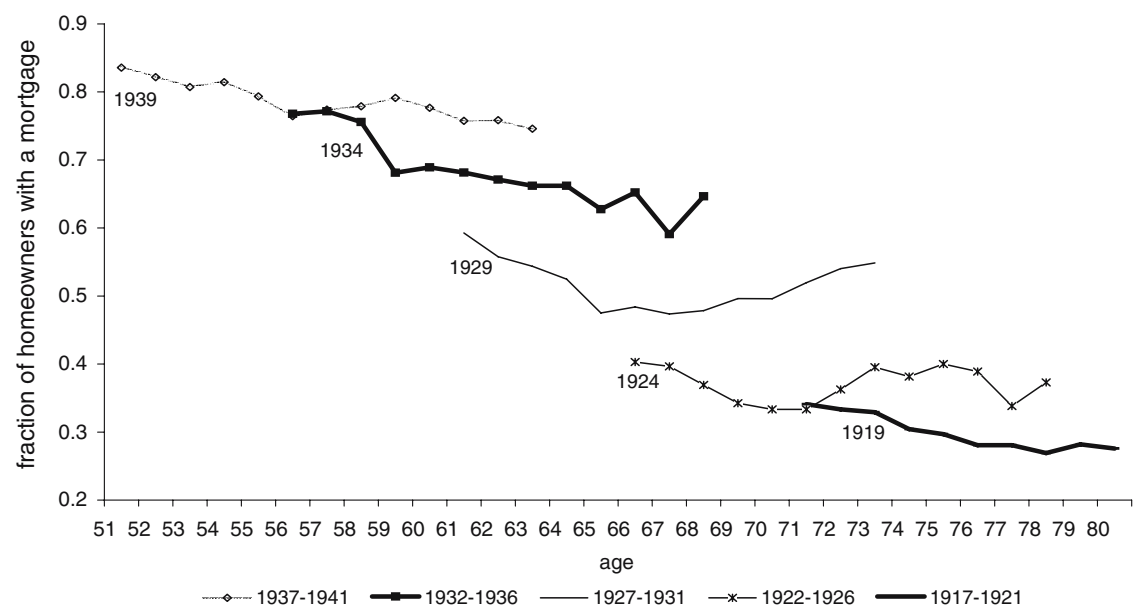

Figure 3 - Mortgage ownership among home owners by age and cohort. Source: SEP, own computations

we can no longer disentangle cohort, age and time effects. Surprisingly, Figure 3 does not show clear evidence for an age-time effect. We do not see a clear decline in mortgage ownership with age for all cohorts as common wisdom would suggest.

From the descriptive analysis presented above we do not really explain the cohort and time effects in home and mortgage ownership. In the next section, we present a panel data model which can be used for this purpose. 


\section{ECONOMETRIC MODEL}

We analyse the home and mortgage ownership using a random effect linear probability model. In order to relax the stringent assumptions of the random effect model, we allow for correlation between unobserved household effects and the explanatory variables by adding household specific averages of the time varying regressors to the model (Mundlak (1978)). We also control for possible sample selection biases -due to panel attrition- by including selectivity dummies. This leads to the following model, explaining home ownership of household $h$ belonging to cohort $c$ in period $t$ :

$$
\begin{aligned}
y_{h, t}= & \alpha_{o}+\sum_{i=1}^{I} \delta_{i} s_{i}\left(\operatorname{age}_{h, t}\right) \\
& +\sum_{\tau=1990}^{2001} \sigma_{\tau} S D_{h, \tau}+Z_{c}^{\prime} \lambda+X_{h, t}^{\prime} \beta+W_{h}^{\prime} \zeta+\omega_{h}+\varepsilon_{h, t},
\end{aligned}
$$

where the selectivity dummy $S D_{h, \tau}$ takes on the value one if the household participates in year $\tau$ and participates at least one more time in the survey after period $\tau(\tau=1990, \ldots, 2001)$. Otherwise the dummy is equal to zero. If the selectivity dummies are jointly significant, there is an attrition bias problem. The age effect, $\sum_{i=1}^{I} \delta_{i} s_{i}\left(\right.$ age $\left._{h, t}\right)$, is modelled by means of a linear spline function with 10 knots at ages $30,40,45,50,55,60,65,70,75$ and 80 . The $\delta$-coefficients reflect the marginal effect of becoming 1 year older for the ages within each interval.

In our approach, we explicitly model the cohort effects by means of a vector of cohort specific variables $Z_{c}$. We assume that cohort effects are driven by productivity differences and by the situation on the real estate market at the time the household head entered the housing market, which we take to be around age $25^{7}$. As we already mentioned in the introduction, we have included three cohort variables in equation (1). The first one reflects the economic situation, using log (GDP per capita) ${ }^{8}$. The other two variables are the logarithm of the amount of newly built houses in the owneroccupied and rental sector respectively, expressed per head of the population between the age of 20 and 30 . We have to point out that the exact number of newly built houses (by ownership type) is not available before 1960. We have imputed the unavailable data on the base of data concerning new constructions and the number of new rented and owner-occu-

7 For each household the value belonging to each cohort variable is an average of the values of the cohort variable in the years in which the head is $23,24,25,26$ and 27. We admit that this choice is slightly arbitrary. Therefore we experimented with age ranges (e.g. by taking the ranges $21-25,25-29$ and 21-29 instead of 23-27). The estimation results are barely affected by the choice of age range (see Van der Schors et al. (2007) for more details).

8 GDP in prices of 1990. 
pied houses ${ }^{9}$. A sensitivity analysis shows that small adjustments in the extrapolation technique do not lead to significant changes of our results. In order to correct for residual trending cohort effects, the vector $Z_{c}$ also includes a cohort trend variable (log year of birth). This variable has no specific economic interpretation; it only corrects for possible spurious correlations. Ideally, one would have liked to add more cohort specific variables such as the stock of houses by ownership type instead of the new supply. However, we need time series from 1930 onwards and time series for those variables are hardly available.

The $X_{h, t}$ vector consists of variables like income, marital status and a dummy variable for being a two-earner household after 1993. The latter reflects the relaxation of credit restrictions in the Netherlands. $W_{h}$ is a vector of time invariant and individual specific variables, like gender, education level and households specific averages of $X_{h, t}$. The individual effect $\omega_{h}$ is assumed to be random and uncorrelated with the right-hand side variables of equation (1). The error term $\varepsilon_{h, t}$ is assumed to be uncorrelated with all right-hand side variables in all time periods. In our estimation procedure, we correct the standard errors for intra-household correlation.

The model for mortgage ownership differs in one respect from that of home ownership. Cohort effects are not explicitly modelled. Instead aggreagate time effects are taken into account. Specific differences are explained in the discussion of the estimation results for mortgage ownership. Evidently, the two models are highly interrelated as the model explaining mortgage ownership is estimated on the subsample of home owners. This selection might generate a bias in the estimation results. Ideally, we would like to correct for this by means of a Heckman selection bias model. However, we do not dispose of exclusion restrictions, because the decisions to buy a house and negotiate a mortgage are taken jointly.

\section{RESULTS}

\subsection{Home Ownership}

Table 1 shows the estimation results for the home ownership model. In Model 1 all households aged $25-80$ are taken into account $(N=57,212)$. In Model 2 , on the right panel of the table, only those households are selected whose head is older than $50(N=23,941)$. We also consider this subsample in order to

9 The information on dwellings built by the (local) government, the housing corporations and private individuals/organisations as well as the total newly built houses is also available before 1960. The annual number of new rented houses is elicited by adding up the new houses owned by the government, the housing corporations and $3 / 10$ built by private parties. The remainder, $7 / 10$ of all private houses, represents the supply of new houses in the owner-occupied sector. After 1960, the exact number of newly built rented and owner-occupied houses is known. The fractions of $3 / 10$ th and $7 / 10$ th are estimated on basis of data after 1960 . 
investigate in more detail the claim that the housing market at young ages has a long term effect on home ownership. The lower part of the table reports five tests of joint significance of the explanatory variables. The joint significance of the household specific averages of the time varying variables, like income, confirms our speculation that the unobserved effects are correlated with time-varying characteristics. The fact that the selectivity dummies are jointly significant in Model $1\left(\chi^{2}(12)=28.35\right)$ shows that attrition does not take place randomly. In Model 2, however, the selectivity dummies are not jointly significant. Therefore we re-estimated this model without including those dummies.

The estimation results for Model 1 suggest that the probability to be home owner increases with $6.4 \%$-points each year in the youngest age group, while it declines with about $0.3 \%$-points per annum after age 65 , ceteris paribus. The estimation results for the 50+ subsample also suggest a decline in home ownership after retirement. The effect is somewhat larger than in model 1: from the age of 65 , we find an annual decrease in ownership of about $0.6 \%$ points. Whereas the direction of the age effects are approximately the same for the two samples, the effect of the other variables dramatically differs between Model 1 and 2 .

In both models the cohort variables are jointly significant at a $1 \%$ significance level (respectively, $\chi^{2}(3)=87.3$ and $\chi^{2}(3)=52.6$ ). This suggests that the economic and housing market situation at the potential age of entry into the housing market partly determines whether or not a household eventually will become a home owner. In Model 1, a 1\% increase in the supply of new owner-occupied houses per head of the population between age 20 and 30 leads to a significant increase in the home ownership rate of $0.09 \%$-points. A $1 \%$ increase in the supply of new rented houses decreases the probability to be home owner by $0.12 \%$-points. These opposite effects indicate that the composition of the stock of newly built houses when the household's head is around age 25, affects a household's final position on the housing market. In the Netherlands, the housing supply is highly regulated. Although the housing shortage has decreased in the last few decades, there is still a discrepancy between the demand and supply for (owner occupied) houses, especially for some specific types and locations (Boelhouwer (2005)). Since (semi-)public institutions have a large say in the construction of new houses in the owner-occupied and rental sector, they have a large influence on home ownership. Our results indicate that an increase in the new supply of houses in the owner-occupied sector enhances starters' opportunities to buy a house. In this way, the excess demand for owner-occupied housing is diminished.

Contrary to our expectations, a $1 \%$ increase in the GDP level per capita leads to a decrease in the home ownership rate ${ }^{10}$. However, this effect is not

10 We also performed a sensitivity analysis in order to check whether business cycle shocks at young ages matter. In other words, we added the variable 'real growth in GDP per cap- 
TABLE 1 - ESTIMATION RESULTS ON HOME OWNERSHIP FOR TWO DIFFERENT AGE GROUPS

\begin{tabular}{|c|c|c|c|c|}
\hline & \multicolumn{2}{|l|}{ Model 1} & \multicolumn{2}{|l|}{ Model 2} \\
\hline & $\begin{array}{l}\text { Parameter } \\
\text { estimates }\end{array}$ & St. err. & $\begin{array}{l}\text { Parameter } \\
\text { estimates }\end{array}$ & St. err. \\
\hline \multicolumn{5}{|l|}{ Cohort variables } \\
\hline $\begin{array}{l}\text { 1: Supply of newly owner-occupied } \\
\text { houses per capita }\end{array}$ & $0.09 * * *$ & 0.015 & 0.017 & 0.016 \\
\hline 2: Supply of newly built rented & & & & \\
\hline houses per capita & $-0.12 * * *$ & 0.013 & -0.00 & 0.016 \\
\hline 3: Absolute level of GDP per capita & -0.07 & 0.055 & $0.17 * * *$ & 0.033 \\
\hline Log (income) & $0.009 * * *$ & 0.002 & 0.0009 & 0.002 \\
\hline$\overline{\log (\text { income })}$ & $0.096 * * *$ & 0.007 & $0.1163^{* * *}$ & 0.013 \\
\hline Two-earner household (yes =1) & 0.001 & 0.008 & -0.0001 & 0.012 \\
\hline Year after $1993($ yes $=1)$ & -0.01 & 0.0 & -0.008 & 0.004 \\
\hline $\begin{array}{l}\text { Two-earner after } 1993 \\
\text { (intro two-earner rule) }\end{array}$ & $0.030^{* * *}$ & 0.009 & 0.0069 & 0.012 \\
\hline Intermediate education & $0.046^{* * *}$ & 0.012 & 0.008 & 0.022 \\
\hline $\begin{array}{l}\text { Higher vocational and university } \\
\text { education }\end{array}$ & $0.080 * * *$ & 0.013 & $0.08 * * *$ & 0.021 \\
\hline Family size & $0.021 * * *$ & 0.004 & $0.013^{*}$ & 0.008 \\
\hline \multicolumn{5}{|l|}{$\begin{array}{l}\text { Marital status } \\
\text { (ref.group }=\text { single, never married) }\end{array}$} \\
\hline Married $($ yes $=1)$ & $0.111^{* * *}$ & 0.019 & 0.0243 & 0.023 \\
\hline Divorced $($ yes = 1) & 0.03 & 0.026 & $-0.06^{*}$ & 0.034 \\
\hline Widow $($ yes = 1) & $0.101 * * *$ & 0.027 & 0.0042 & 0.019 \\
\hline Sex $($ male $=1)$ & $0.089 * * *$ & 0.014 & $0.0611 * *$ & 0.025 \\
\hline \multicolumn{5}{|l|}{ Age splines } \\
\hline $25-30$ & $0.064 * * *$ & 0.004 & & \\
\hline $30-40$ & $0.022 * * *$ & 0.001 & & \\
\hline $40-45$ & $0.008 * * *$ & 0.002 & & \\
\hline $45-50$ & $0.01 * * *$ & 0.002 & & \\
\hline $50-55$ & $0.0068^{* * *}$ & 0.002 & $0.0048 * *$ & 0.002 \\
\hline $55-60$ & $0.006^{* *}$ & 0.002 & 0.0040 & 0.002 \\
\hline $60-65$ & 0.002 & 0.002 & -0.0002 & 0.002 \\
\hline $65-70$ & $-0.002^{*}$ & 0.002 & $-0.004 * * *$ & 0.001 \\
\hline $70-75$ & $-0.003^{* *}$ & 0.002 & $-0.005^{* * *}$ & 0.002 \\
\hline $75-80$ & -0.003 & 0.002 & $-0.006^{* * *}$ & 0.002 \\
\hline Cohort trend variable & $0.43^{* * *}$ & 0.072 & & \\
\hline Constant term & -2.9788 & 0.469 & $-2.328 * * *$ & 0.34 \\
\hline$N$ & 5,7212 & & 2,3941 & \\
\hline
\end{tabular}


TABLE 1 - continued

\begin{tabular}{|c|c|c|c|c|}
\hline & \multicolumn{2}{|c|}{ Model 1} & \multicolumn{2}{|c|}{ Model 2} \\
\hline & $\begin{array}{l}\text { Parameter } \\
\text { estimates }\end{array}$ & St. err. & $\begin{array}{l}\text { Parameter } \\
\text { estimates }\end{array}$ & St. err. \\
\hline $\begin{array}{l}\text { Joint significance (chi square test): } \\
\text { Household specific averages }\end{array}$ & $\chi_{7}^{2}=303 * * *$ & & $\chi_{7}^{2}=99 * * *$ & \\
\hline Age splines & $\chi_{10}^{2}=525^{* * *}$ & & $\chi_{6}^{2}=32 * * *$ & \\
\hline Income variables & $\chi_{2}^{2}=211^{* * *}$ & & $\chi_{2}^{2}=77 * * *$ & \\
\hline Cohort variables & $\chi_{3}^{2}=85^{* * *}$ & & $\chi_{3}^{2}=53^{* * *}$ & \\
\hline Selectivity dummies & $\chi_{12}^{2}=28 * * *$ & & not included & \\
\hline
\end{tabular}

Explanatory note: Model 1: all ages between 25 and 80. Model 2: 50+ respondents. Significance levels $* * *=1 \% ; * *=5 \% ; *=10 \%$. We do not present the estimated coefficients of the household specific averages, except from the time average of $\log$ (income). The cohort trend variable is a log trend based on year of birth. We dropped the cohort trend variable from Model 2 because of non-significance.

The selectivity dummies are jointly significant in the total sample, but not in the $50+$ model. Therefore, they are included in Model 1 and dropped in Model 2.

Source: SEP, own computations

statistically significant. A possible explanation for this result is the fact the cohort trend variable is highly significant. The cohort trend variable appears to be highly correlated with GDP per capita (correlation coefficient $=0.971$ ). The high significance of the cohort trend variable signals the presence of unobserved, trending cohort effects. One of such trending cohort effects could be the house prices (relative to the rents) at the moment of entering the housing market.

Total household income appears to have a significant positive effect on home ownership. Notably, we can make a distinction between the effect of permanent and transitory income: the household specific average of $\log ($ income $),(\overline{\log (\text { income })})$, serves as a proxy variable for permanent income. However, we should be careful with interpreting the variable. For the elderly subsample the permanent income consists of 13 years of income after retirement. This underestimates a household's real permanent income. In Model 1 , a $1 \%$ increase in permanent income leads to a rise in the home owner-

ita' around age 25 as an extra regressor in the model (next to GDP in levels). In both the full and the 50+ sample this extra variable was not statistically significant (see Van der Schors et al. (2007)). 
ship rate of $0.11 \%$-points ${ }^{11}$. The transitory income component has a small, but significant effect on home ownership. In Model 2 only the variable measuring the household's specific average of $\log ($ income), $(\overline{\log (\text { income })})$, contributes positively to the probability to be home owner ( $0.12 \%$-points). On basis of the Model 1 results we find that for two-earner households after 1993, the probability to be home owner significantly increases, ceteris paribus, by 3\%-points. The three variables that measure the effect of being a twoearner household after 1993 are jointly significant at a $1 \%$ significance level $\left(\chi^{2}(3)=33.87\right)$. It suggests that the relaxation of credit constraints for twoearner households increases the chance of two-earner households to buy a house (at the cost of one-earner households). However, the three indicators are not jointly statistically significant if we consider the 50+ sample. Also the individual dummy variable that indicates whether or not a household is a two-earner household after 1993 is insignificant for this subsample. Apparently, many of the elderly two-earner households do no longer plan to become home owner despite the existence two-earner rule.

If we only take the elderly households into account (cf. Model 2), the effect and significance of the cohort variables strongly deviate from those in Model 1. Model 2 does not contain a cohort trend, since the coefficient estimate of this variable did not differ significantly from zero. In Model 2 the two housing supply variables around age 25 are no longer significant. This suggests that the housing market conditions when entering the housing market have no effect on home ownership for the elderly sample. On the other hand, the GDP per capita around age 25 is highly significant. A $1 \%$ increment in the GDP per capita increases home ownership by $0.18 \%$-points ${ }^{12}$. Possibly, the initial macro economic situation affects the income situation of a household in later periods and hence the opportunities to buy a house. This is quite plausible, despite the fact that we have already included proxy variables for transitory and permanent income. Those proxy variables might be imperfect, since the permanent income proxy only takes the income of 13 years into account. For most elderly households (i.e. the households considered in Model 2) this means that the permanent income is an average of mainly pension income, which is expected to be lower than the income during working life. The GDP cohort variable, on the contrary, reflects the effect of being born (and raised) in a specific period with specific economic conditions, for example in the period before World War II or just after 1945.

11 The effect of the permanent income on home ownership is equal to the coefficient of income variable itself (transitory component) plus the coefficient of the variable related to the household specific average of income.

12 We examined the effect of including the GDP growth as an additional cohort variable, to account for the effect of changes in the economic situation. Because this potential cohort variable was not significant in any of the estimations (see Van der Schors et al. (2007)), we decided not to include this variable. 


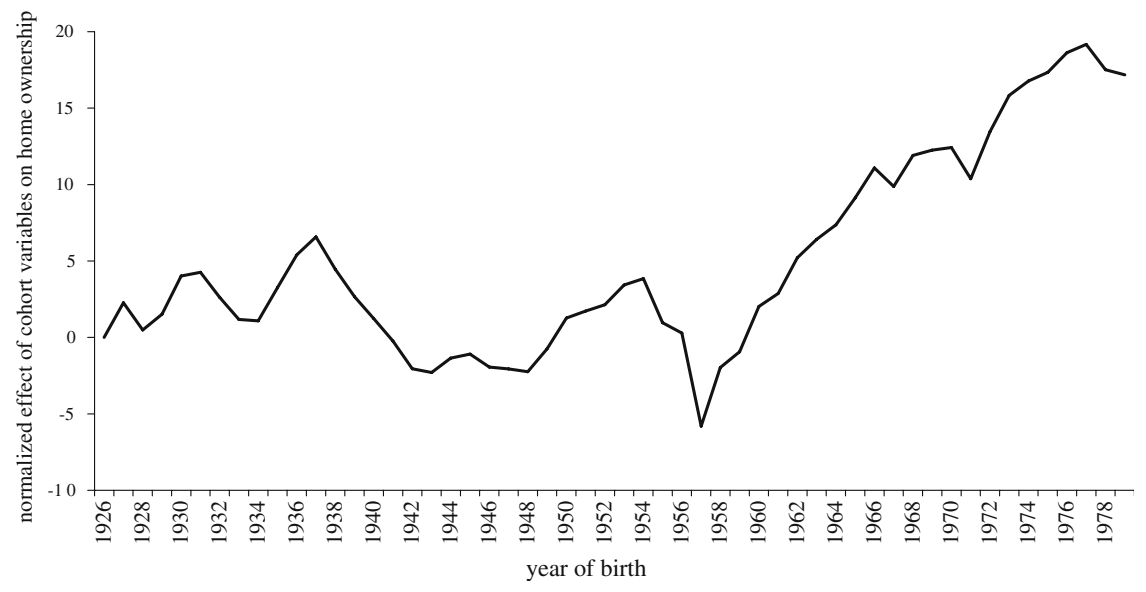

Figure 4 - The joint effect of the cohort variables on home ownership (all ages). Explanatory note: the figure is based on the estimation results from Model 1 (whole sample). The vertical axis is normalised to zero in year 1926.

Source: own computations

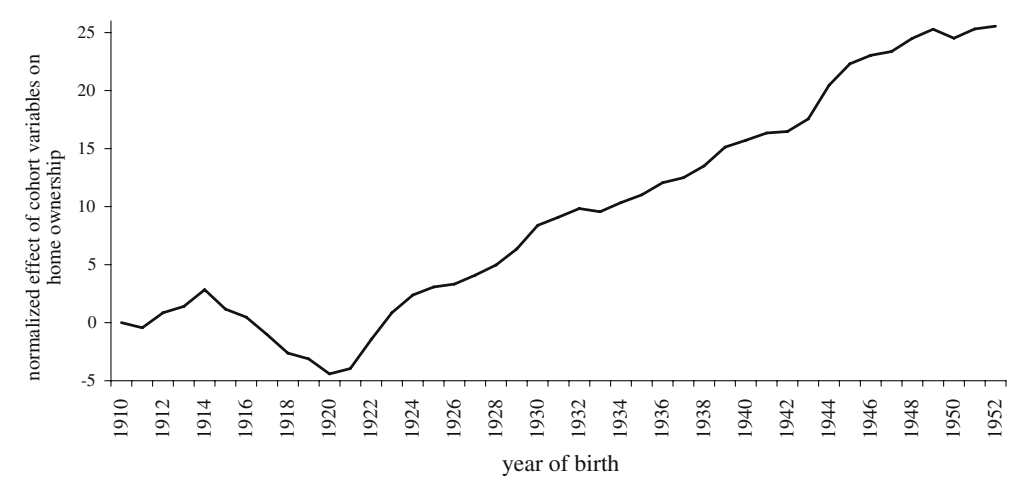

Figure 5 - The joint effect of the cohort variables on home ownership (households above age 50). Explanatory note: the figure is based on the estimation results from Model 2 (ages between 50 and 80). The vertical axis is normalised to zero in year 1910.

Source: own computations

Figure 4 shows the joint effect of the cohort variables by year of birth on basis of the results of Model $1^{13}$. The cohort effect is normalised to zero for the first year of birth in the graph (1926). Between birth years 1926 and 1960 we do not observe a clear pattern. From 1960 onwards, we see strong

13 The joint effect is computed by multiplying for each year of birth the coefficient of each of the cohort variables by the value of the cohort variables. Afterwards, we take the sum of the three multiplications for each year of birth. In computing the joint effect, we do not take the cohort trend variable into account. 
positive cohort effects: comparing the 1966 and 1978 generations, there is a difference of $10 \%$-points in the home ownership rate. On the base of Figure 4 it seems that the cohort variables only explain differences in home ownership between younger generations of households, consistent with our speculations above. Figure 5 shows the effect of the cohort variables when we use the coefficients estimated in Model 2. Notice that in Figure 5 the cohort effect is mainly driven by the GDP variable. Contrary to Figures 4 and 5 suggests positive cohort effects among the elderly cohorts: the probability to be home owner is $15 \%$-points higher for households with a head born in 1950, compared to those born in 1930.

Altogether, the fact that the estimation results of Models 1 and 2 differ dramatically suggests that in Model 1 interactions between cohort variables and age should be taken into account. Consequently, we think that the results based on the 50+ subsample describe more adequately the cohort effects of the elderly households. To check whether the three cohort specific variables satisfactorily describe the cohort effects, we include a full set cohort dummies to the model (results not displayed) ${ }^{14}$. If the coefficients corresponding to the cohort dummies are jointly insignificant, the included cohort variables explain most of the cohort effects. It appears that the cohort dummies are not jointly significant at a $1 \%$ significance level $\left(\chi^{2}(37)=30.24\right)$. So, for the $50+$ subsample, it seems that the GDP per capita and the two housing supply variables at the potential age of entry on the housing market describe most cohort effects.

\subsection{Mortgage Ownership}

Table 2 summarises the estimation results of the model explaining mortgage ownership. In this analysis, we only select home owners older than 50 because we do not expect respondents to be able to redeem their mortgage at younger ages (see Figure 2 in section 2). This reduces the sample to 11,533 observations, which refer to 2,223 households. The models explaining mortgage ownership and home ownership differ in several respects. First, we do not explicitly model generation effects, because we could not find appropriate cohort specific variables and the relevant data. Instead, we use a linear spline function of year of birth which contains six knots. The second difference is that we account for time effects in explaining mortgage ownership. By including time dummies to measure the time effect, we would run into the wellknown identification problem: because of the identity calender year $=$ age + year of birth, one cannot disentangle age, cohort and time effects. We solve this identification problem by explicitly modelling the time effect by means of

14 To avoid perfect collinearity problems (we included three cohort specific variables), we need to drop arbitrarily three cohort dummies. 
TABLE 2 - MORTGAGE OWNERSHIP AMONG HOME OWNERS BETWEEN AGE 50 AND 80

\begin{tabular}{|c|c|c|}
\hline & Coefficient & St.error \\
\hline Inflation rate (as a \%) & $0.007 * * *$ & 0.002 \\
\hline Log(average house price) & $0.136^{* * *}$ & 0.043 \\
\hline Years of living in the current home & -0.001 & 0.001 \\
\hline Relative value of the house & $0.008 *$ & 0.005 \\
\hline Log (total income) & -0.003 & 0.005 \\
\hline$\overline{\log (\text { income })}$ & $0.037 * * *$ & 0.012 \\
\hline Intermediate education & 0.030 & 0.021 \\
\hline Higher vocational and university education & $0.061 * *$ & 0.024 \\
\hline Family size & -0.004 & 0.009 \\
\hline \multicolumn{3}{|l|}{ Marital status (ref.group $=$ single, never married $)$} \\
\hline Married $($ yes $=1)$ & -0.110 & 0.090 \\
\hline Divorced $($ yes = 1) & -0.088 & 0.110 \\
\hline Widow $($ yes $=1)$ & -0.071 & 0.097 \\
\hline Sex $($ male $=1)$ & -0.001 & 0.036 \\
\hline \multicolumn{3}{|l|}{ Age splines } \\
\hline $50-55$ & $-0.015^{* * *}$ & 0.004 \\
\hline $55-60$ & $-0.013 * * *$ & 0.005 \\
\hline $60-65$ & $-0.025^{* * *}$ & 0.005 \\
\hline $65-70$ & $-0.015^{* * *}$ & 0.006 \\
\hline $70-75$ & -0.005 & 0.007 \\
\hline $75-80$ & $-0.016^{* * *}$ & 0.006 \\
\hline \multicolumn{3}{|l|}{ Birth cohorts splines } \\
\hline before 1927 & -0.001 & 0.006 \\
\hline $1927-1931$ & $0.021 * *$ & 0.011 \\
\hline $1932-1936$ & -0.003 & 0.010 \\
\hline 1937-1941 & $0.015^{* *}$ & 0.008 \\
\hline 1942-1946 & -0.005 & 0.006 \\
\hline $1947-1952$ & $-0.021 * * *$ & 0.007 \\
\hline Constant & $-1.202 * * *$ & 0.398 \\
\hline$N$ & 11,533 & \\
\hline \multicolumn{3}{|l|}{ Joint significance of (chi square test) : } \\
\hline Household specific averages & $\chi^{2}(7)=31.32$ & \\
\hline Age splines & $\chi^{2}(6)=34.67$ & \\
\hline Cohort splines & $\chi^{2}(6)=36.18$ & \\
\hline Income variables & $\chi^{2}(2)=10.38$ & \\
\hline
\end{tabular}

Explanatory note: The model includes all ages between 50 and $80 . * * *=$ significant at $1 \%$ confidence level; $* *=$ significant at $5 \%$ confidence level; $*=$ significant at $10 \%$ confidence level. The use of the real interest rate instead of the inflation rate as a time specific variable does hardly affect the results. The real interest rate itself has a significant negative effect on mortgage ownership (see Van der Schors et al. (2007)). Source: SEP, own computations 
the inflation rate and the real average house price during the sample period ${ }^{15}$. Finally, the model explaining mortgage ownership includes two extra household specific variables. One regressor reports the value of one's house relative to the average house price at the housing market ${ }^{16}$. The other one indicates the length of residence in the current home. In our econometric model we do not take into account that the possibility to deduct mortgage interest payments from taxable income has been curtailed somewhat from the year 2001 onwards ${ }^{17}$. This reform could only have an effect in the last year of the sample period. We expect that households do not directly respond to such reforms and hence the effect is expected to be limited.

As we expected, the age spline coefficient estimates are negative and differ significantly from zero $\left(\chi^{2}(6)=34.7\right)$. So, each year the head of the household becomes older, the probability of having a mortgage decreases. However, it is rather surprising that the size of the age effects fluctuates instead of becoming more strongly negative when older. This result is in accordance with the age profile we saw in Figure 3.

The cohort splines are jointly significant $\left(\chi^{2}(6)=36.2\right)$. The empirical evidence suggests that mortgage ownership is a non-decreasing function of the year of birth up to 1946. If the head of the household was born in 1937 the probability to be mortgage owner is $6 \%$-points larger, relative to the households in which the head was born in 1927 . These results partly explain the cohort-time effects observed in Figures 2 and 3. The size of the positive cohort effect differs among generations.

Both the inflation rate and the logarithm of the house prices have a significant positive effect on mortgage ownership. These are the indicators that correct for time effects and should therefore pick up the business cycle. If one expects higher inflation in the near future it becomes financially attractive to take up a mortgage. Of course we do not know whether current inflation can signal for future inflation expectations, though many studies have found evidence of this (Engelberg et al. (2006)). The effect of inflation indeed appears to be positive and significant. A $1 \%$ increase in the house prices results in an increase in the mortgage ownership rate by $0.14 \%$-points. Possibly, this might imply that an increase in house prices induces households to cash the surplus value on their house by negotiating a mortgage again ${ }^{18}$. Similar to

15 We have obtained data on the average house prices from the Dutch foundation of real estate agents (Nederlandse Vereniging voor Makelaars). The prices are corrected for inflation each year. 16 These values are expressed in prices of 1990.

17 As of 2001, the tax deductibility of mortgage interest payments is restricted to a maximum duration of 30 years. Moreover, the interest can only be deducted if the mortgage is used for the finance of the house or home improvements and no longer for consumption purposes. 18 If we use the real interest rate instead of the inflation rate as a time specific variable, the estimation results remain rather constant. It does hardly affect the age and cohort effects. The real interest rate itself has a significant negative effect on mortgage ownership (see Van der Schors et al. (2007)). 
the misspecification test on the cohort specific variables, we test whether the two time variables satisfactorily describe the time effect. Therefore, we include all time dummies to the model (results not displayed) ${ }^{19}$. The null hypothesis, which states that the coefficients corresponding to the time dummies are jointly equal to zero, cannot be rejected at a $1 \%$ significance level $\left(\chi^{2}(9)=\right.$ 11.50). This suggests that we effectively capture most time effects by means of the inflation rate and house prices.

Besides the age, time and cohort effects, it seems that the average log (total income), our proxy for the permanent income, significantly contributes to the explanation of mortgage ownership. The effect is however small: a $1 \%$ increase enhances the probability to have a mortgage with $0.034 \%$-points. Transitory income has no significant effect. Furthermore, the results show that the number of years living in the current home does not significantly affect the probability to have a mortgage. Finally, it appears that the probability to be mortgage owner is an increasing function of the ratio of the house value and the average house price in the Netherlands.

\section{COHORT EFFECTS IN MORTGAGE OWNERSHIP: A FURTHER ANALYSIS}

In the home ownership models, we are able to explain the cohort effects. However, this is not true for the model that considers mortgage ownership. Ideally, we would have liked to include generation specific variables to describe those cohort effects. However, relevant aggregate data are barely available. A second problem is that the SEP does not contain much information on the mortgage contract. For instance we do not know when the mortgages are taken up. Therefore, we resort to a more descriptive analysis to explain the cohort effects in mortgage ownership observed in the previous section. For this purpose, we use information from the DHS data to discuss some of the issues that have arisen, or that we could not account for, in the previous section. Contrary to the SEP, this DHS questionnaire includes questions about the residual duration of a mortgage, bequest and savings motives and the popularity of several mortgage types.

Figure 6 shows that for each age above 50, the number of years elapsed since the arrangement of the mortgage is smaller in 2005 than in 1993: the difference is about 3 years. Although it cannot fully explain the cohort effect in mortgage ownership, the shift in the age of mortgage take up could be one of the candidate explanations. This shift in the age of mortgage take-up might be explained by the fact that younger generation households move more frequently than the old ones. An alternative explanation might be that in comparison with the older generation younger cohorts have a higher tendency to 're-mortgage' their house after the completion of the initial mortgage

19 To avoid linear combinations, we need to drop four time dummies; year 1990-1993. 


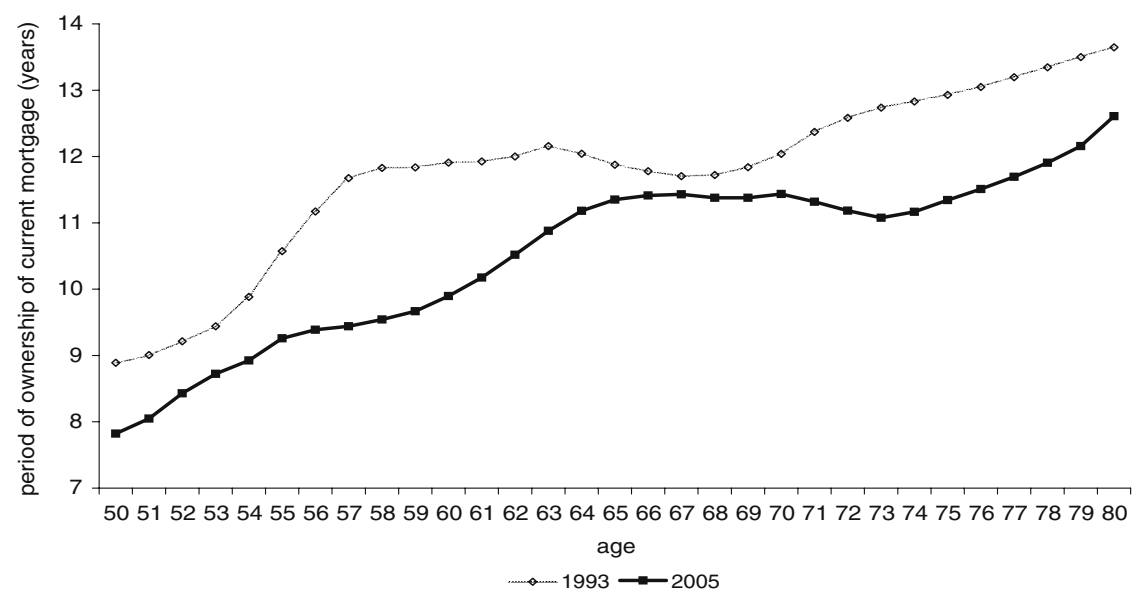

Figure 6 - Time from mortgage arrangement in 1993 and 2005 (in years).

Explanatory note: lowess smoothing has been used to determine the relation between age and remaining mortgage duration.

Source: DHS, own computations

contract. From other data sources, we get the impression that the last explanation is more plausible. Statistics Netherlands (1999) for instance reports that in the third quarter of 1999 about $60 \%$ of the new mortgages were used to exploit the increase in the house value to buy other durable goods and to finance stock market operations.

Although, we cannot prove this directly, our speculation is strengthened by the fact that the increase in first mortgages is accompanied by a considerable rise in the number of home owners with a second mortgage ${ }^{20}$. It increases from almost zero to about $10 \%$ for the retired elderly (see Figure 7) between 1993 and 2005. Second mortgages are mostly used to cash the surplus value for other purposes. In the last waves of the DHS-survey, in 2003 to 2005, home owners who cashed the surplus value were asked for what purpose they used the mortgage loan. The majority of the respondents reports that they have employed this for home improvements $(55 \%)$. Home improvements can be regarded as a way to increase the market value of the house and also allow the home owner to enjoy an extra tax facility. Merely $18 \%$ of the respondents used it for the purchase of durable goods. In other words, the use of housing wealth to finance consumption does not seem to be very popular yet. It should be mentioned, however, that from 2001 onwards mortgage interest payments are no longer tax deductible if the mortgage is used to finance dura-

20 One speaks of a second mortgage if a household indicates that it has two mortgage contracts outstanding on the same dwelling. 


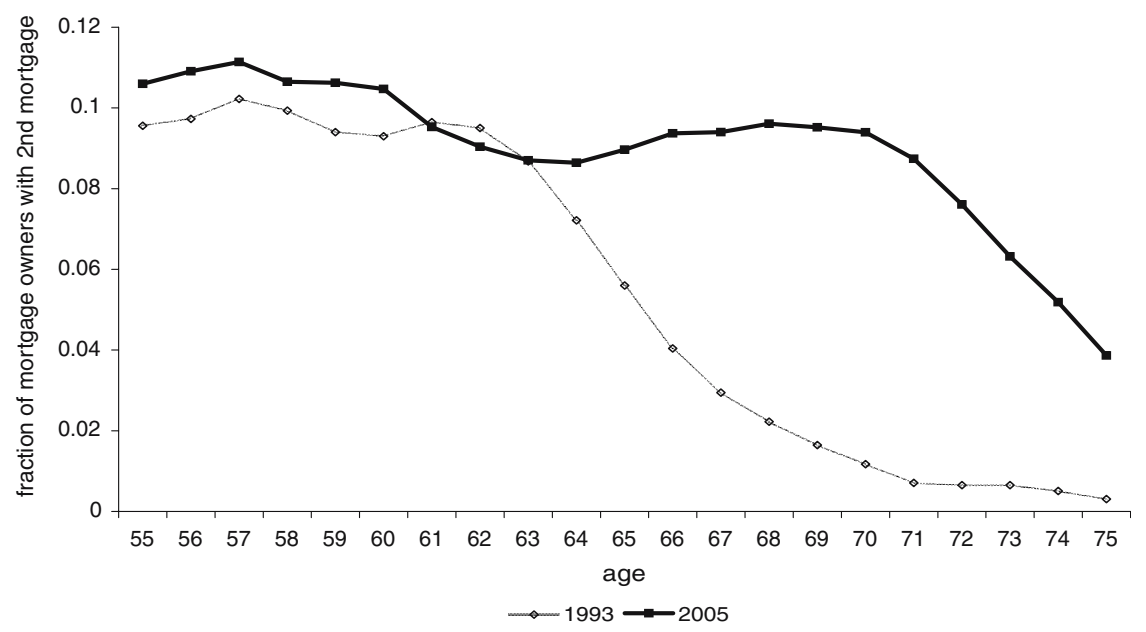

Figure 7 - The fraction of mortgage owners with a second mortgage in 1993 and 2005. Explanatory note: lowess smoothing has been used to determine the relation between age and second mortgage ownership.

Source: DHS, own computations

ble expenditures (except for the purpose of home improvement) or stock market operations.

Another explanation for the generational differences in mortgage ownership could be related to changes in elderly's attitude towards leaving a bequest. More often, parents realise that their children are well educated and hence will be financially well off. Therefore, younger generation parents could find it less important to bequeath their house to their children (Hurd (1990)). Instead, they can use the housing wealth to finance consumption after retirement. The DHS-survey includes the following interesting question:

Please indicate which of the following four statements about parents leaving a bequest to their children, would be closest to your own opinion about this.

1. If our children would take good care of us when we get old, we would like to leave them a considerable bequest.

2. We would like to leave our children a considerable bequest, irrespective of the way they will take care of us when we are old.

3. We have no preconceived plans about leaving a bequest to our children because we want to enjoy our own lives.

4. We don't intend to leave a bequest to our children, because we don't want to do that.

5. NONE of the above-mentioned statements. 
It should be noted that more than $60 \%$ of the respondents selects the third option indicating that many respondents do not find it important to leave a bequest. Their bequests would mostly be accidental. We compare the answers to this question in 1993 with 2003 by looking at elderly (55+) home owners. It appears that between 1993 and 2003, the fraction of home owners with an accidental bequest motive increased significantly (from 57 to 64\%). This result suggests that leaving a bequest has become a slightly less important saving motive.

Finally, financial innovation could have contributed to the increase in the mortgage ownership rate. We see that the increase is accompanied by an increase in the popularity of the interest-only mortgage. Whereas in $199330 \%$ of all elderly mortgage owners between 60 and 70 years old had an interest-only mortgage, this share has risen to $50 \%$ in 2005 . This large increase is mirrored in the reduction of the annuity mortgage. It is unclear how the increase in the interest-only mortgage relates to the increase in mortgage ownership in general; the causality could be in both directions. In future research it would be interesting to analyse the elderly's choice for this specific mortgage type.

\section{SUMMARY AND CONCLUSION}

In this study, we have investigated home and mortgage ownership of the Dutch elderly. In the descriptive analysis, we establish that among the elderly there are considerable generational differences in the home ownership rate. We have developed an econometric model which, among other things, can be used to explain those cohort effects. Even after correction for important background characteristics, such as income and education level, cohort effects remain important. The main factor explaining the generational differences in home ownership is by the level of GDP per capita when the household head was about 25 years old. This cohort specific variable has been included in order to account for generational differences in permanent income. However, if we take the whole sample into account it appears that the supply of new owner-occupied and rented houses per capita between the age of 20 and 30 affects home ownership. Interestingly, the situation at the housing market does no longer explain generational differences when looking at the households above age 50 in particular. These highly deviating results suggest that interaction effects between cohort and age effects play an important role. In future research the existence of such interactions should be explored in more detail using a larger dataset such as the Income Panel Survey (IPO - this is an administrative dataset collected by Statistics Netherlands).

Our results suggest that during retirement home ownership decreases with age. It might be worthwhile to investigate this further using a transition 
model (Tatsiramos (2004)). Again, data from IPO might prove useful here, since transitions out of home ownership to nursing homes are relevant when observing elderly. Such a study is not possible with SEP because households in institutions, like nursery homes, are excluded from the sample frame.

The fraction of elderly home owners that has a mortgage debt has also increased considerably during the nineties. Around age 60 the mortgage ownership is much higher for home owners born around 1935 relative to those born around 1930. This difference amounts to $20 \%$-points. Instead of modelling the cohort effects, we explain the time effects by including two time specific variables, namely house prices and the inflation rate. It appears that these variables capture most of the time effects. The cohort splines in the econometric model are jointly significant, indicating that cohort effects should be taken into account when explaining mortgage ownership. A supplementary analysis has been performed in order to gain a better understanding of the causes underlying this residual cohort and time effects. It appears that among the retirees the accidental motive to leave a bequest has become more important during the nineties. Moreover, financial innovation, residual mortgage duration and the take up of second mortgages all contribute to the explanation of the increase in mortgage ownership of the elderly, though their effect is not always unambiguous. The supplementary analysis presented in the paper is rather descriptive. A more thorough multivariate analysis seems to be necessary. Nevertheless, our analysis shows that both time and cohort effects contribute to the explanation of the strongly increased mortgage ownership among elderly home owners.

\author{
Anna van der Schors* \\ Rob J.M. Alessie** \\ Mauro Mastrogiacomo***
}

\title{
REFERENCES
}

Alessie, R., A. Lusardi and A. Kapteyn (1995), 'Saving and Wealth Holding of the Elderly, Ricerche Economiche, 49, pp. 293-315.

Alessie, R., A. Kapteyn and F. Klijn (1997), 'Mandatory Pensions and Personal Savings in the Netherlands,' Economist, 3(145), pp. 291-324.

* Corresponding author: Utrecht School of Economics (USE), Utrecht University, Janskerkhof 12, 3512 BL, Utrecht, The Netherlands, Phone: 030-2534283, fax 030-2537373, e-mail: A.vanderSchors@econ.uu.nl

${ }^{* *}$ Utrecht School of Economics (USE), Utrecht University, Janskerkhof 12, 3512 BL, Utrecht, The Netherlands, and CPB (Netherlands bureau for Economic Policy Analysis), Van Stolkweg 14, P.O. Box 80510, 2508 GM, The Hague, The Netherlands

${ }^{* * *}$ CPB (Netherlands bureau for Economic Policy Analysis) Van Stolkweg 14, P.O. Box 80510, 2508 GM, The Hague, The Netherlands, and Vrije Universiteit Amsterdam, De Boelelaan 1105, 1081 HV, Amsterdam, The Netherlands, e-mail: m.mastrogiacomo@cpb.nl 
Alessie, R. and A. Kapteyn (2002), 'Huizenprijzen en Besparingen,' in: R. Alessie, P. van Els and L. Hoogduin (eds.), De Rol Van Vermogen in de Economie, BNG, Preadviezen voor de Koninklijke Vereniging van de Staathuishoudkunde, Den Haag, pp. 31-56.

Boelhouwer, P.J. (2005), 'The Incomplete Privatization of the Dutch Housing Market: Exploding House Prices versus Falling House-Building Output,' Journal of Housing and the Built Environment, 20, pp. 363-378.

Chiuri, M. and T. Jappelli (2000), 'Financial Market Imperfections and Home Ownership: A Comparative Study,' Fisciano, Centre for Studies in Economics and Finance.

Chiuri, M. and T. Jappelli (2006), 'Do the Elderly Reduce Housing Equity; an International Comparison,' Fisciano, Centre for Studies in Economics and Finance.

Deaton, A. (1992), Understanding Consumption. Oxford New York, Oxford University Press.

Disney, R., A. Henley and G. Stears (2002), 'Housing Costs, House Price Shocks and Savings Behaviour among Older Households in Britain,' Regional Science and Urban Economics, 32 , pp. 607-625.

Engelberg, J., C. Manski and J. Williams (2006), 'Comparing the Point Predictions and Subjective Probability Distributions of Professional Forecasters,' NBER Working Papers, (11978).

Groeneveld, J.M. and R.T.A. de Haas (1999), 'De Schuld van de Huishoudens,' Economisch Statistische Berichten, 84.

Haffner, M.E.A. (2005), 'Appel voor de Dorst?; Vermogen van Ouderen op de Woningmarkt,' Nethur.

Hurd, M.D. (1989), 'Mortality Risk and Bequests,' Econometrica, 57(2), pp. 779-813.

Hurd, M.D. (1990), 'Research on the Elderly: Economic Status, Retirement and Consumption and Saving II,' Journal of Economic Literature, XXVIII, pp. 565-637.

Kapteyn, A., R. Alessie and A. Lusardi (2005), 'Explaining the Wealth Holdings of Different Cohorts: Productivity Growth and Social Security,' The European Economic Review, 49, pp. 1361-1391.

Ministry of Housing, Spatial Planning and Environment (1999), Evaluatie Nota Volkshuisvesting in de Jaren Negentig, Ministry of Housing, Spatial Planning and Environment, The Hague.

Mundlak, Y. (1978), 'On the Pooling of Time Series and Cross Section Data,' Econometrica, XXVII(46), pp. 69-85.

Nyhus, E. (1996), 'The VSB-CentER Savings Project: Data Collection Methods, Questionnaires and Sampling Procedures,' VSB-CentER Savings Project Progress Report no. 42, Tilburg University.

Rouwendal, J. and R. Alessie (2002), 'House Prices, Second Mortgages and Household Savings; an Empirical Investigation for the Netherlands, 1987-1994,' Tinbergen Institute Discussion Papers, TI 2002-074/3.

Statistics Netherlands (1999), 'Hypotheekmarkt Overtreft Alle Records,' Press Release PB99285.

Tatsiramos, K. (2004), 'Residential Mobility and the Housing Adjustment of the Elderly: Evidence for the ECHP for Six European Countries,' European University Institute/IZA.

Van Assenbergh, W. (1998), 'De Ene Hypotheek is de Andere Niet,' Economisch Statistische Berichten, (83), 36-38.

Van der Schors, A., R. Alessie and M. Mastrogiacomo (2007), 'Home and Mortgage Ownership of the Dutch Elderly: Explaining Cohort, Time and Age Effects', $C P B$ discussion paper, 77. 